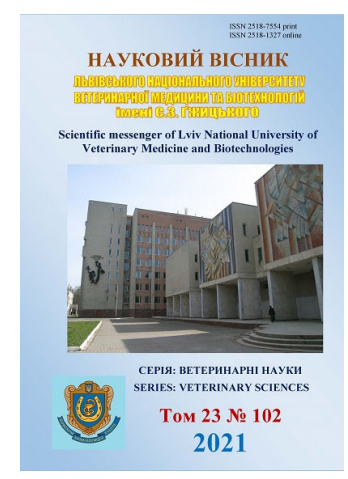

Науковий вісник Яьвівського національного університету ветеринарної медицини та біотехнологій імені С.3. Гжицького. Серія: Ветеринарні науки

Scientific Messenger of Lviv National University of Veterinary Medicine and Biotechnologies. Series: Veterinary sciences doi: $10.32718 /$ nvlvet10218 https://nvlvet.com.ua/index.php/journal

UDC 636:636.5/.6:330.3(477.83/.86)

\title{
Dynamics of poultry and the current state of poultry in the Western region of Ukraine
}

\author{
R. I. Fedyniak, M. M. Verkholiuk, O. V. Yaremko, R. A. Peleno \\ Stepan Gzhytskyi National University of Veterinary Medicine and Biotechnologies, Lviv, Ukraine
}

Article info

Received 04.05.2021

Received in revised form 07.06.2021

Accepted 08.06.2021

Stepan Gzhytskyi National University of Veterinary Medicine and Biotechnologies Lviv, Pekarska Str., 50, Lviv, 79010, Ukraine. Tel.: +38-096-874-68-35 E-mail: romannafeduniak@ukr.net
Fedyniak, R. I., Verkholiuk, M. M., Yaremko, O. V., \& Peleno, R. A. (2021). Dynamics of poultry and the current state of poultry in the western region of Ukraine. Scientific Messenger of Lviv National University of Veterinary Medicine and Biotechnologies. Series: Veterinary sciences, 23(102), 119-124. doi: $10.32718 /$ nvlvet10218

One of the most attractive and promising types of agrarian business in Ukraine is poultry farming, the rapid development of which ensures high competitiveness, due to the short period of production, lower compared to other food products of animal origin, price and high demand among consumers. Now, the market of our country has significantly increased demand for turkey meat, which has practically no contraindications, as it does not contain cholesterol, is a gentle, hypoallergenic, dietary product that is rich in unsaturated fatty acids, including omega-3, proteins, essential amino acids, minerals, vitamins $A$ and $B$, etc. The purpose of the work was to investigate the dynamics of poultry in the period from 2011 to 2020 and to get the current state of poultry in general, and turkey farming in particular, in the Western region of Ukraine. It is found that in the period from 2011 to 2020 the largest number of poultry, 9548.3 \pm 447.1 thousand, was kept in farms of Lviv region, slightly less $-8109.1 \pm 546,1$ thousand of Khmelnytsk region, even less $-7222.1 \pm 121.0$ and $7682.9 \pm 316.2$ thousand Volynj and Rivne regions. The farms of IvanoFrankivsk, Ternopilj, Transcarpathian and Chernivtsi regions was kept $5290.8 \pm 284.75200 .2 \pm 86.2$, $4127.6 \pm 115.2$ and $3636.7 \pm 50.5$ thousand poultry, respectively. The largest poultry population in the farms of Lviv and Volynj regions was in 2020 and amounted to 11938,1 and 8822.4 thousand, respectively, Rivne region - 7742.3 thousand in 2018, Transcarpathian - 4385.8 thousand in 2015, Chernivtsi - 3863.9 thousand in 2012, Ternopilj - 5584.2 thousand in 2019, Khmelnytskyj - 10864.5 thousand in 2014 and Ivano-Frankivsk - 6761.1 thousand in 2011.The lowest number of poultry in farms of Lviv, Rivne, Volynj, Transcarpathian, Ternopilj, Khmelnytskyj regions was in 2011, the number of which was 7961.5, 6721.2, 5933.7, 3126.1, 4681.6, 5069.7 thousand, respectively, and Chernivtsi and Ivano-Frankivsk - 3376.5 and 4175.7 thousand in 2016 and 2017. The smallest number of turkey farms in Western Ukraine was in the period from 2011 to 2013. By 2017, there was an increase in their number by $20 \%$, and in $2018-a$ decrease of $10 \%$ compared to 2017. In 2019, the number of registered enterprises increased by $18.18 \%$, compared to 2018, and in 2020 their number was the largest.

Key words: poultry farming, turkey farms, turkeys, poultry, statistics, Western region of Ukraine.

\section{Динаміка поголів'я птиці та сучасний стан птахівництва у Західному регіоні України}

\author{
Р. І. Фединяк, М. М. Верхолюк, О. В. Яремко, Р. А. Пеленьо
}

Львівський національний університет ветеринарної медицини та біотехнологій імені С. 3. Гэсицького, м. Львів, Украӥна

Одним із найбільш привабливих і перспективних видів аграрного бізнесу в Украӥні є птахівництво. Його стрімкий розвиток забезпечує висока конкурентоздатність, обумовлена коротким терміном виробництва, нижчою, порівняно з іншими харчовими продуктами тваринного походження, ціною та високим попитом серед споживачів. Нині на ринку нашої держави суттєво зріс 
попит на м'ясо індиків, щзо практично не має протипоказань, оскільки не містить холестерину, є ніжним, гіпоалергенним, дієтичним продуктом, багатим ненасиченими жирними кислотами, включно з омега-3, протеїнами, незамінними амінокислотами, мінералами, вітамінами груп $A$ i B тошо. Метою роботи було дослідити динаміку поголів'я птиці у період з 2011 по 2020 рік та з'ясувати сучасний стан розвитку птахівництва в иілому та, зокрема, індиківництва в Західному регіоні Украӥни. Встановлено, шо в період з 2011 по 2020 рік найбільша кількість птиці, 9548,3 \pm 447,1 тис., утримувалася в господарствах Львівської області.

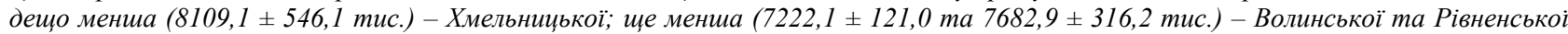
областей відповідно. У господарствах Івано-Франківської, Тернопільської, Закарпатської та Чернівецької областей утримувалося відповідно 5290,8 \pm 284,7; 5200,2 \pm 86,2; 4127,6 \pm 115,2 та 3636,7 \pm 50,5 тис. птиці. Найбільшим поголів'я птиці у господарствах Львівської та Волинської областей було у 2020 роиі і становило відповідно 11938,1 та 8822,4 тис., Рівненської області 7742,3 тис. у 2018 роиі, Закарпатської - 4385,8 тис. у 2015 роиі, Чернівецької - 3863,9 тис. у 2012 роиі, Тернопільської- 5584,2 тис. у 2019 роиі, Хмельницької-10864,5 тис. у 2014 роиі та Івано-Франківської- 6761,1 тис. у 2011 роиі. Наймение птиці у господарствах Львівської, Рівненської, Волинської, Закарпатської, Тернопільської, Хмельнииької областей було в 2011 році, їі кількість становила відповідно 7961,5; 6721,2; 5933,7; 3126,1; 4681,6; 5069,7 тис., а Чернівецької та Івано-Франківської - 3376,5 і 4175,7 тис. у 2016 та 2017 роках. Найменшою кількість індичих господарств на Заході України була у період з 2011 по 2013 рік. До 2017 відбулося збільшення їх кількості на 20\%, а в 2018 ройі-зменшення на 10\%, порівняно із 2017 роком. У 2019 році кількість зареєстрованих підприємств зросла на 18,18\%, порівняно із 2018 роком, і в 2020 рочі їх кількість була найбільшою.

Ключові слова: птахівництво, індичі господарства, індики, поголів'я птиці, статистичні дані, Західний регіон Украӥни.

\section{Вступ}

Одним найбільш привабливим і перспективним видом аграрного бізнесу в Україні є птахівництво. Стрімкий розвиток птахівничої галузі відбувається за рахунок ії високої конкурентоздатності, обумовленої коротким терміном виробництва продукції, іiі нижчою, порівняно із іншими харчовими продуктами тваринного походження, ціною та високим попитом серед споживачів (Vinichenko \& Makhovskyi, 2015; Prokopyshyn, 2019). М'ясо птиці є висококалорійним, поживним, містить велику кількість повноцінного протеїну, вітамінів, мікро- та макроелементів, які легко засвоюються організмом людини і є необхідними для його нормального функціонування (Marangoni et al., 2015; Przybylski et al., 2021).

Впродовж останніх років Україна змогла досягти не лише повного самозабезпечення м'ясом птиці, але й перейшла до його експорту. Зростанню кількості птиці в нашій державі сприяло зменшення виробництва м'яса інших видів тварин (Karpenko, 2016; Melnyk, 2019). М'ясо птиці стало замінником яловичини та свинини для переважної кількості споживачів (Buryak, 2017).

Нині на ринку нашої держави встановлено суттєве зростання попиту на м'ясо індиків. Вони належать до розряду великих птахів, максимальна маса тіла яких може досягати 30 кг. Забійну вагу, яка становить в середньому 15 кг, вони набирають за півроку. Порівняно із курми, індики практично не хворіють сальмонельозом, а вихід м'язової тканини, зокрема грудини, є на 12-15 \% більший (Buryak, 2017; Abbas et al., 2018).

Індичатина не має протипоказань, так як $є$ гіпоалергенним продуктом. Вона дієтична, ніжна, низькокалорійна, не містить холестерину, проте містить ненасичені жирні кислоти, включаючи омега-3, велику кількість протеїну, незамінних амінокислот, мінералів, вітамінів груп А і В та добову норму для людини вітаміну PP (Zampiga et al., 2018).

Традиційно більшість поголів'я індиків утримувалося в індивідуальних господарствах. Інтенсивний розвиток промислового індиківництва в Україні, за даними аналітиків компанії Pro-Consulting, розпочався у 2002 році. 3 цього часу виробництво індича- тини щорічно зростає приблизно на $10 \%$, а рентабельність бізнесу становить 20-25\%. Проте, навіть за таких умов, кількість виробленого м'яса у 2018 році була 27230 тис. тонн, в той час, як потреба лише внутрішнього ринку, становить 90-100 тис. тонн на рік (Markina \& Bolshakova, 2019).

Забезпечити таку потребу можливо лише за рахунок збільшення обсягів власного виробництва даної продукції, або іiі імпорту (Slavova, 2020). Щоб збільшити власне виробництво необхідно удосконалювати вже існуючі та розробляти нові технології вирощування та переробки, створювати сучасні підприємства і нарощувати поголів'я індиків.

Метою роботи було дослідити динаміку поголів'я птиці у період з 2011 по 2020 рік та встановити сучасний стан птахівництва в цілому, i, індиківництва зокрема, у Західному регіоні України.

Для досягнення поставленої мети необхідно:

- визначити кількість поголів'я птиці та його динаміку у господарствах Західного регіону України за період з 2011 по 2020 рік;

- дослідити динаміку кількості промислових індичих господарств.

\section{Матеріал і методи досліджень}

Стан та розвиток птахівничої галузі та індиківництва на Заході України здійснювали на підставі даних статистичної звітності за період з 2011 по 2020 рік, оприлюднених на офіційних сайтах Державного комітету статистики України у Львівській, Рівненській, Волинській, Закарпатській, Чернівецькій, Тернопільській, Хмельницькій та Івано-Франківській областях.

Дані піддавали статистичній обробці, яку проводили на персональному комп'ютері за допомогою програми STATISTICA 7.0 з визначенням середніх значень величин і середньої похибки. Одержані результати групували в діаграми та проводили порівняльний аналіз.

\section{Результати та їх обговорення}

Проведення моніторингових досліджень розвитку різних галузей народного господарства $\epsilon$ важливим, 
так як їх результати дають змогу встановити слабкі та сильні сторони та визначити оптимальні шляхи усунення існуючих проблем. Нині, українська економіка забезпечує сприятливі умови для швидкого розвитку птахівництва. За результатами аналізу статистичних даних (рис. 1) встановлено, що за період з 2011 по 2020 рік у господарствах Західного регіону України утримувалося від 44114,9 до 54892,3 тис. птиці.

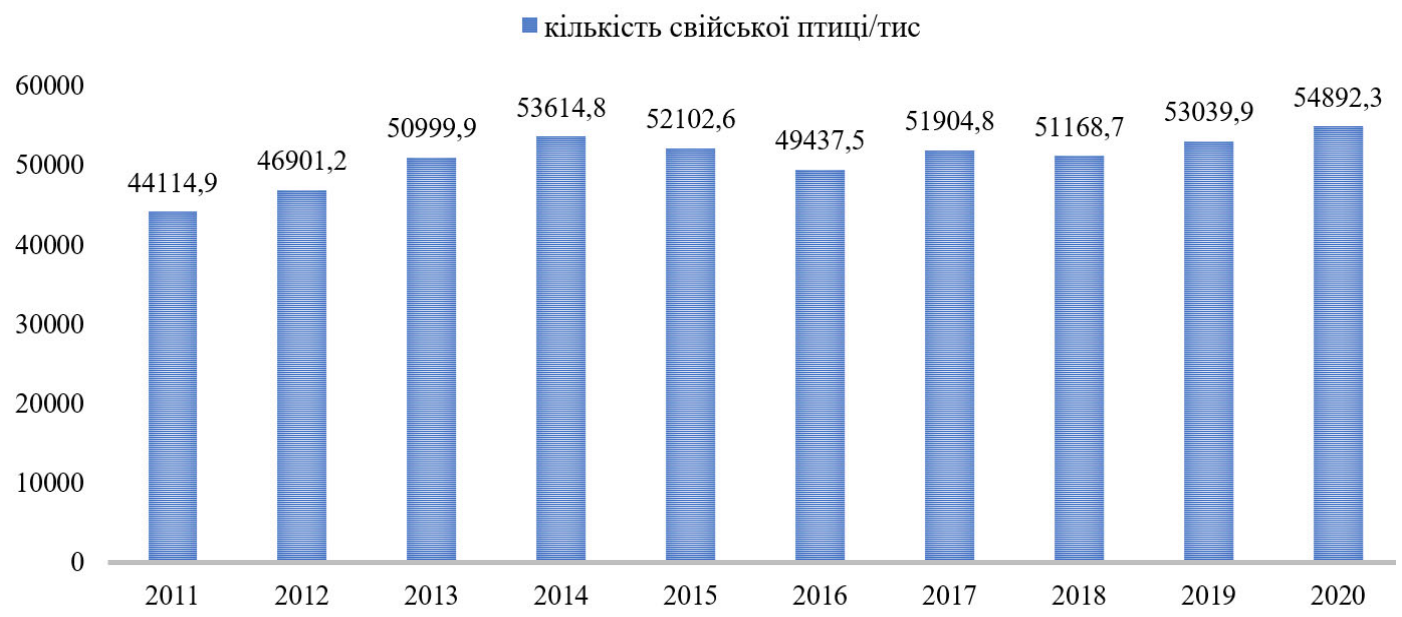

Рис. 1. Загальна кількість птиці у господарствах Західного регіону України в період з 2011 по 2020 рік.

Найменше поголів’я птиці (44114,9 тис.) було зареєстровано у 2011 році. До 2014 року встановлено зростання кількості птиці. Зокрема, у 2012 році поголів'я, порівняно із 2011 роком, зросло на 6,3\%, у 2013 році - на 15,6 \% і у 2014 році - на $21,5 \%$ і становило відповідно 46901,2, 50999,9 і 53614,8 тис.

У 2015 та 2016 роках чисельність поголів'я птиці зменшилася, порівняно із 2014 роком на 2,8 та $13,4 \%$ i становила відповідно 52102,6 та 49437,5 тис. У 2017 році встановлено зростання на 5,0\% кількості птиці, порівняно із 2016 роком, а у 2018 році - його зменшення на $3,5 \%$. У наступних роках поголів'я птиці у господарствах Західного регіону поступово збільшувалося і досягло максимальної кількості 54892,3 тис. у 2020 році.

За період з 2011 по 2020 рік найбільша кількість птиці, 9548,3 \pm 447,1 тис. (рис. 2), утримувалася у господарствах Львівській області. На 15,07 \% менше птиці, порівняно із Львівщиною, у господарствах Хмельницької області, поголів'я в яких становило $8109,1 \pm 546,1$ тис. Ще менше, 7222,1 $\pm 121,0$ та $7682,9 \pm 316,2$ тис. птиці, було зареєстровано у господарствах Волинської та Рівненської областей і різниця, порівняно із Львівською областю, становила відповідно 24,36 \%. та 19,53\%.

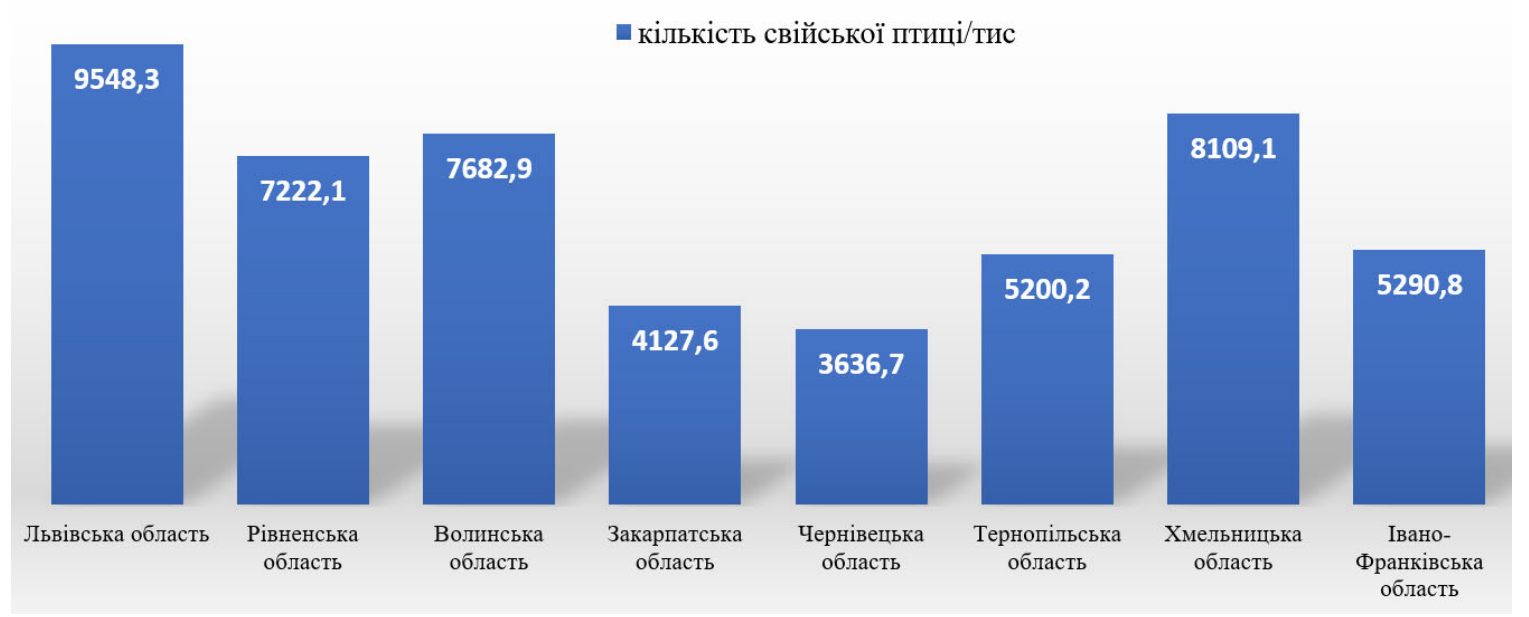

Рис. 2. Середня кількість птиці у господарствах Західного регіону України за період 2011-2020 pp.

На 44,58, 45,53 та 56,77 \% меншою, порівняно із Львівською областю, була кількість птиці у господарствах Івано-Франківської, Тернопільської та Закарпатської областей, в яких чисельність поголів'я становила відповідно $5290,8 \pm 284,7, \quad 5200,2 \pm 86,2$ та $4127,6 \pm 115,2$ тис. Найменша кількість птиці, $3636,7 \pm 50,5$ тис., утримувалась у господарствах Чер- нівецької області і, порівняно із Львівщиною, різниця становила $61,91 \%$.

У господарствах Львівської області (рис. 3) кількість птиці у 2011 році була 7961,5 тис. До 2014 року поголів'я зросло на 13,8 \% і становило 9063,1 тис., а до 2016 році - зменшилося до 8241,2 тис., або на 3,5 \%. За період з 2017 по 2020 рік встановлено пос- 
тупове зростання кількості птиці. Так, у 2017 році, чисельність поголів'я була 10046,48 тис., у 2018 році - 10826,54 тис, у 2019 році - 11422,36 тис. та у 2020 році - 11938,13 тис. і різниця, порівняно із 2016 роком, становила відповідно 17,9, 23,8, 27,8 і 30,9 \%.

У Рівненської області кількість птиці в господарствах у 2011 році була 6721,21 тис., поступово зростала впродовж наступних 7 років і у 2018 році становила 7742,3 тис. У 2019 році поголів'я зменшилося на
233,3 тис., а у 2020 році - зросло до 7705,88 тис. За період з 2011 по 2020 рік у господарствах Волинської області поголів'я птиці зросло $3 \quad 5933,65$ до 8822,38 тис., або на 48,7 \%. У Закарпатській області кількість птиці у 2011 році була 3126 тис., до 2015 року щороку зростала відповідно на 28,9, 34,7, 36,9 та 40,3 \% і з 2016 по 2020 рік знаходилося в межах від 4212,65 до 4344,17 тис. птиці.

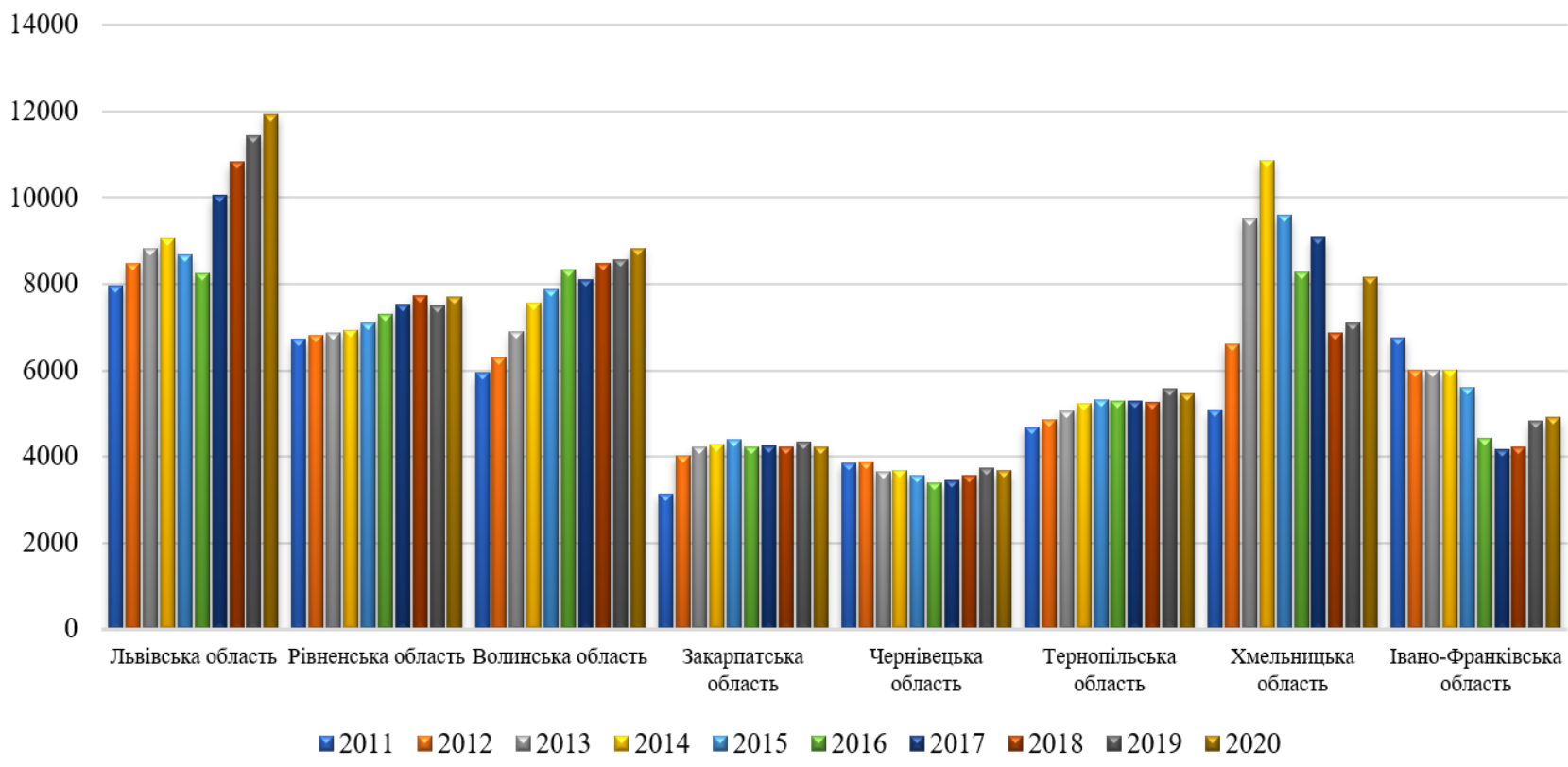

Рис. 3. Динаміка птиці у господарствах Західного регіону України у період 2011-2020 pp.

Аналізуючи кількість птиці у господарствах Чернівецькій області встановлено, що найбільшим поголів'я було у 2011 році (3860,2 тис.), впродовж наступних років поступово зменшувалося і було найменшим (3376,5 тис.) у 2016 році. 32017 року чисельність птиці зростала, у 2019 році досягла 3719,38 тис. і знизилася до 3671,43 тис. у 2020 році.

У господарствах Тернопільської області зростання поголів'я 3 4681,6 до 5314,9 тис. було 32011 по 2015 рік, у 2016-2018 роках відбулося незначне зниження кількості птиці, а в 2019 році - зростання на 6,51\% до 5584,2 тис. У 2020 році кількість птиці знизилася на 2,04 \%, порівняно із 2019 роком, і становила 5470 тис.

У Хмельницької області з 2011 по 2014 рік поголів'я птиці збільшилося з 5069,7 до 10864,5 тис., знизилося на 11,8 та 23,9\% у 2015 та 2016 роках, а в 2017 році було 9078,8 тис. Впродовж наступних двох років поголів'я знизилося на 24,4 та $21,9 \%$ і становило відповідно 6864,9 та 7091,6 тис. У 2020 році кількість птиці збільшилася на 1065,7 тис., або 15,02\%, порівняно із 2019 роком і в цьому році вона була більшою на 3087,6 тис., або 60,91\%, порівняно 3 2011 роком.

На відміну від більшості областей Західного регіону в Івано-Франківській області найбільшою
(6761 тис.) кількість птиці була у 2011 році. У 2012 поголів'я зменшилося на $11,35 \%$, або 767,5 тис., а в 2013 та 2014 роках, відзначено незначне його збільшення. Впродовж наступних трьох років знову відбулося зменшення поголів'я, яке становило відповідно 6,84, 26,62 та $30,61 \%$ та збільшення 32018 до 2020 року. У останні три роки кількість птиці становила $4225,4,4812,7$ та 4908,4 тис.

3 динаміки кількості птахогосподарств у Західному регіоні України за період 2011-2020 рр. (рис. 4) встановлено, що найменша їх кількість була у 2011 та 2012 роках. 32013 до 2017 року кількість господарств, що утримують птицю, була більшою на 21,92$28,81 \%$, знизилася на 7,75 \% у 2018 році, знову зросла на13,43\% у 2019 році та знизилася на 3,07\% у 2020 році.

Подібні зміни встановлено і у кількості господарств, що утримують індиків. Зокрема, їх кількість була найменшою у період з 2011 по 2013 рік і становила 8 господарств. 32014 по 2017 рік кількість індичих господарств, як і птахогосподарств в цілому, зросла на $20 \%$, знизилася на $10 \%$ у 2018 році та зросла на 18,18\% у 2019 році. В 2020 році, як і у 2019 році, кількість індичих господарств у Західному регіоні України була найбільшою і становила 11 господарств. 


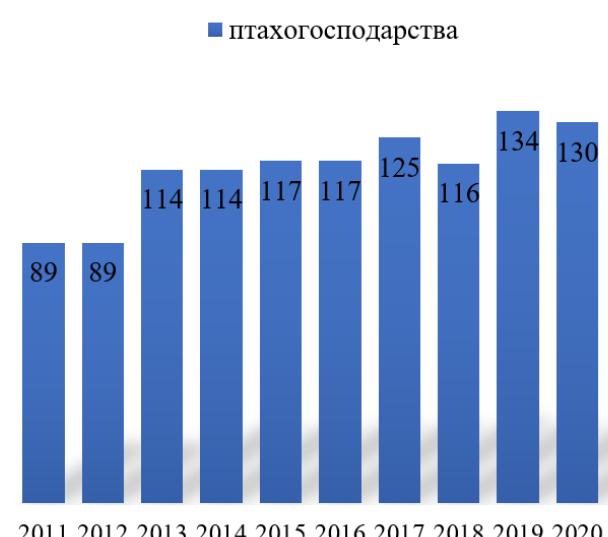

Рис. 4. Динаміка кількості птахогосподарств у Західному регіоні України за період 2011-2020 pp.

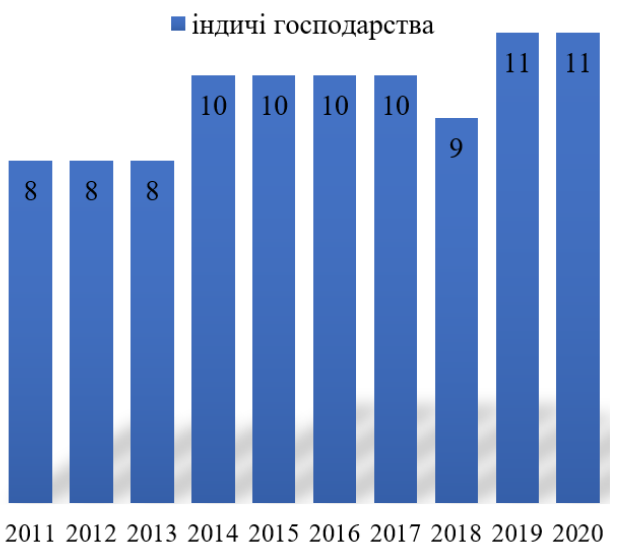

of animal origin. Food Chemistry, 246, 6-17. doi: 10.1016/j.foodchem.2017.11.007.

Buryak, R. I. (2017). Doslidzhennya ta prohnozuvannya konyunktury rynku produktsiyi ptakhivnytstva Ukrayiny. Naukovyy visnyk Natsionalnoho universytetu bioresursiv i pryrodokorystuvannya Ukrayiny. Seriya: Ekonomika, ahrarnyy menedzhment, biznes, 260, 41-53. URL: http://journals.nubip.edu.ua/index.php/Economica/arti cle/view/8556 (in Ukrainian).

Derzhavna sluzhba statystyky Ukrayiny u Chernivetskiy oblasti: URL: http://www.cv.ukrstat.gov.ua (in Ukrainian).

Derzhavna sluzhba statystyky Ukrayiny u IvanoFrankivskiy oblasti: URL: https://www.ifstat.gov.ua (in Ukrainian).

Derzhavna sluzhba statystyky Ukrayiny u Khmelnytskiy oblasti: URL: http://www.km.ukrstat.gov.ua/ukr/ index.htm (in Ukrainian).

Derzhavna sluzhba statystyky Ukrayiny u Lvivskiy oblasti: URL: https://www.lv.ukrstat.gov.ua (in Ukrainian).

Derzhavna sluzhba statystyky Ukrayiny u Rivnenskiy oblasti: URL: http://www.gusrv.gov.ua (in Ukrainian).

Derzhavna sluzhba statystyky Ukrayiny u Ternopilskiy oblasti: URL: http://www.te.ukrstat.gov.ua (in Ukrainian).

Derzhavna sluzhba statystyky Ukrayiny u Volynskiy oblasti: URL: http://www.lutsk.ukrstat.gov.ua (in Ukrainian).

Derzhavna sluzhba statystyky Ukrayiny u Zakarpatskiy oblasti: URL: http://www.uz.ukrstat.gov.ua (in Ukrainian).

Karpenko, S. M. (2016). Osnovni tendentsiyi rozvytku ptakhivnytstva. Ékonomyka y menedzhment, 7, 2-9. URL: http://www.ait-magazine.com.ua/sites/default/ files/karpenko.pdf (in Ukrainian).

Kopytets, N. H., \& Voloshyn, V. M. (2019). Otsinka tsinovoyi sytuatsiyi na rynku myasa ptytsi. Ekonomika APK, 11, 42-48. doi: 10.32317/22211055.201911042 (in Ukrainian).

Marangoni, F., Corsello, G., Cricelli, C., Ferrara, N., Ghiselli, A., Lucchin, L., \& Poli, A. (2015). Role of poultry meat in a balanced diet aimed at maintaining health and wellbeing: an Italian consensus document. Food \& Nutrition Research, 59. doi: 10.3402/fnr.v59.27606. 
Markina, I. A., \& Bolshakova, Y. L. (2019). Osoblyvosti funktsionuvannya ta tendentsiyi rozvytku rynku myasa ta myasnoyi produktsiyi v Ukrayini. Ukrayinskyy zhurnal prykladnoyi ekonomiky, 4(4), 119-128. doi: 10.36887/2415-8453-2019-4-14 (in Ukrainian).

Melnyk, V. (2019). Development of poultry farming of Ukraine in the period of independence. Sciences of Europe, 40-3, 45-48.

Prokopyshyn, O. S. (2019). Pidvyshchennya ekonomichnoyi efektyvnosti pidpryyemstv ptakhivnytstva. Ukrayinskyy zhurnal prykladnoyi ekonomiky, 4(3), 8-16. doi: 10.36887/2415-8453-2019-3-1 (in Ukrainian).

Przybylski, W., Jaworska, D., Kajak-Siemaszko, K., Sałek, P., \& Pakuła, K. (2021). Effect of Heat Treatment by the Sous-Vide Method on the Quality of Poultry Meat. Foods, 10(7), 1610. doi: 10.3390/foods10071610.
Slavova, G. (2020). Production of various types of poultry in Bulgaria for the period 2010-2018. Izvestija na Sojuza na uchenite-Varna. Serija Ikonomicheski nauki, 9(1), 3-9. doi: 10.36997/IJUSV-ESS/2020.9.1.3.

Vinichenko, I. I., \& Makhovskyi, D. V. (2015). Stan ta perspektyvy rozvytku ptakhivnychykh pidpryyemstv v Ukrayini. Ahrosvit, 24, 3-6. URL: http://www.agrosvit.info/pdf/24_2015/2.pdf (in Ukrainian).

Zampiga, M., Flees, J., Meluzzi, A. et al. (2018). Application of omics technologies for a deeper insight into quali-quantitative production traits in broiler chickens: A review. J Animal Sci Biotechnol, 9, 61. doi: 10.1186/s40104-018-0278-5. 